\title{
Determining the interviewer effect on CQ Index outcomes: a multilevel approach
}

\author{
Sjenny Winters ${ }^{1,2^{*}}$, Mathilde H Strating ${ }^{2}$, Niek S Klazinga ${ }^{3}$, Rudolf B Kool ${ }^{1}$, Robbert Huijsman ${ }^{2}$
}

\begin{abstract}
Background: The CQ Index for the elderly, a quality-of-care questionnaire administered by conducting interviews, is used to assess clients' experiences in Dutch nursing homes and homes for the elderly. This article describes whether inter-interviewer differences influence the perceived quality of healthcare services reported by residents, the size of this interviewer effect and the influence of the interviewer characteristics on CQ Index dimensions for public reporting.

Methods: Data from 4345 questionnaires was used. Correlations were calculated, reliability analyses were performed, and a multilevel analysis was used to calculate the degree of correlation between two interviewers within one health care institution. Five models were constructed and the Intra Class Correlation (ICC) was calculated. Healthcare institutions were given 1-5 stars on every quality dimensions ( $1=$ worst and $5=$ best), adjusted for resident and interviewer characteristics. The effect of these characteristics on the assignment of the stars was investigated.
\end{abstract}

Results: In a multilevel approach, the ICC showed a significant amount of variance on five quality dimensions. Of the interviewer characteristics, only previous interviewing experience, the reason of interviewing and general knowledge of health care had a significant effect on the quality dimensions. Adjusting for interviewer characteristics did not affect the overall star assignment to the institutions regarding 7 of 12 quality dimensions. For the other five dimensions (Shared decision-making, Meals, Professional competency, Autonomy, and Availability of personnel) a minor effect was found.

Conclusions: We have shown that training, the use of experienced interviewers, written instructions, supervision and educational meetings do not automatically prevent interviewer effects. While the results of this study can be used to improve the quality of services provided by these institutions, several CQ index dimensions should be interpreted with caution for external purposes (accountability and transparency).

\section{Background}

Monitoring the experiences of residents of nursing homes and homes for the elderly is crucial to improve the quality of care and to evaluate the effect of interventions to improve care [1-14]. In an attempt to standardize the method of measuring the experiences of residents in nursing homes and homes for the elderly, in 2006 the Dutch Ministry of Health developed instruments for measuring the experiences of patients in different types of health care facilities [12,15-18]. These questionnaires are based on the CAHPS questionnaires [16]. Also for residents in nursing homes and homes for

\footnotetext{
* Correspondence: sjenny.winters@prismant.nl

${ }^{1}$ Kiwa Prismant, P.O. Box 85200, 3508 AE Utrecht, the Netherlands Full list of author information is available at the end of the article
}

the elderly, a so called CQ Index, has been developed and pilot-tested [12]. In the Netherlands the nursing homes and homes for the elderly differ: the care given in nursing homes is more intensive than care given in homes for the elderly. Dutch nursing homes and homes for the elderly are obliged to have this survey of residents' opinions conducted every two years. The survey must be administered by an accredited, independent organization. The institutions are ranked for the level of quality and this information is available to the public. The results of the CQ Index serve two purposes. Firstly, it can be used by health care institutions to improve the quality of the services they provide. Secondly, it enlarges the accountability and transparency towards insurers, the Inspectorate for Health Care and future clients. 
A commonly used method to assess the healthcare experiences of elderly is a face-to-face interview, in which a standardized questionnaire is administered. Research has shown that face-to-face interviews improve the quality and quantity of the data, and that they are less a burden for respondents when compared to telephone interviews $[19,20]$. Respondents are more likely to comply with a face-to-face interview than with a telephone interview [21] or a written questionnaire [22]. However, face-to-face interviews do have the possible disadvantage of an interviewer effect, which has been found to be greater than in telephone interviews [23]. There are ways in which interviewers can influence the answers given by respondents to pre-formulated questions [24]. Firstly, interviewers can subconsciously express their own attitudes, opinions, or expectations by means of intonation, verbal and non-verbal communications and non-standard explanation of words as formulated in the interviewer guide [25]. Secondly, elderly respondents are likely to have difficulty choosing one of the pre-defined answer categories. Also, a face-to-face interview is an opportunity for social contact. Therefore, respondents often tend to go into a conversation. As a result, the interviewer has to interpret and translate this into one of the answering possibilities. This interpretation is subjective and may differ between interviewers. This could lead to interviewer bias and false conclusions [22].

While several suggestions have been made to overcome these problems [24,26,27], little is known about how to prevent interviewer effects in face-to-face interviews with elderly [28]. It is known that the quality of data obtained from older individuals may also be affected by the respondent's physical, cognitive, and sensory impairments [29], and it is recognized that face-to-face interviews provide older people with an opportunity for social contact [30]. These studies suggest a special training programme for interviewers before interviewing elderly. Although we do know interviewer effects are likely to influence the results of the survey and several suggestions have been made to diminish this, little is known about which interviewer characteristics cause this effect and how large the effect actually is. In this study, we used the CQ Index to investigate 1) whether experienced interviewers (knowledge of nursing homes and homes for the elderly and more than 70 interviews conducted) influence the perceived quality of healthcare services reported by residents of nursing homes and homes for the elderly in the Netherlands (interviewer effects), 2) the size of the interviewer effect when using interviewers with who conducted a major number of interviews in this study (experienced interviewers) and 3) the influence of the interviewer characteristics on results of the CQ Index dimensions for public reporting. We tried to establish whether structural differences in the scores on the CQ Index between experienced interviewers can be explained by interviewer characteristics, and whether these differences influence how these institutions are ranked for overall quality.

\section{Methods}

Between January 2007 and April 2008 trained interviewers from the accredited research organization, Prismant, administered the CQ Index to residents in 24 nursing homes and 109 homes for the elderly. For this research we asked written permission from all participated these health care institutions to use their CQ Index data for scientific purposes, and all institutions cooperate. This data collection is part of a regular research which is conducted every year in the Netherlands. This method of the research is constructed in a collaboration of relevant stakeholders (Ministry of Health, the branch organization and Inspectorate for Health Care) [12].

\section{Subjects}

The research population consisted of residents of nursing homes and homes for the elderly. Residents who had stayed in the facility for less than 1 month, residents who were very ill, residents with psychiatric conditions, or residents who were convalescing were excluded. In total, $29 \%$ of the population met the exclusion criteria. The residents were selected by making a random sample, and tested on representativeness by age and gender.

\section{Questionnaire: CQ Index}

In the first part of the questionnaire, the age, sex, educational level, length of stay and health status of the resident and type of care (nursing home or home for the elderly) was recorded. The central part of the questionnaire consists of 72 questions. Together, these questions represent 15 quality-of-care dimensions (Table 1). All answers were assigned a 1-4 point score, with the higher the score, the less positive the resident experienced the question. The compilation of the scores on the questions to scores on the quality dimensions also resulted in a score ranging from 1 to 4 . Means and standard deviations of the scores were calculated. Reliability was measured using Cronbach's alpha (Table 1). The reliability of the dimensions 5,11 , and 13 was low (Cronbach's alpha $<0.6$ ) so these were excluded from further analysis.

\section{Interviewers}

All interviewers were trained before and during the study - they learned about the content of the 
Table 1 Dimensions of the CQ Index

\begin{tabular}{lcccc}
\hline Dimensions & $\begin{array}{c}\text { Number } \\
\text { of } \\
\text { items }\end{array}$ & $\begin{array}{c}\text { Mean } \\
\text { score }\end{array}$ & sd & $\begin{array}{c}\text { Cronbach's } \\
\boldsymbol{\alpha}\end{array}$ \\
\hline 1. Care plan and evaluation & 1 & 1.71 & .939 & - \\
2. Shared decision making & 5 & 2.14 & .819 & 0.81 \\
3. Treatment & 4 & 1.61 & .663 & 0.81 \\
4. Information & 6 & 1.96 & .781 & 0.75 \\
5. Body care & 3 & 1.49 & .494 & $0.55^{*}$ \\
6. Meals & 1 & 1.93 & .860 & - \\
7. Professional competency & 8 & 1.43 & .469 & 0.82 \\
8. Living comfort & 1 & 1.57 & .823 & - \\
9. Atmosphere & 4 & 1.53 & .484 & 0.63 \\
10. Living environment and & 4 & 1.18 & .354 & 0.62 \\
privacy & & & & \\
11. Activities & 5 & 1.52 & .438 & $0.54^{*}$ \\
12. Autonomy & 4 & 1.52 & .647 & 0.69 \\
13. Mental wellbeing & 3 & 2.19 & .531 & $0.32^{*}$ \\
14. Security & 1 & 1.21 & .542 & - \\
15. Availability personnel & 5 & 2.16 & .581 & 0.67 \\
\hline
\end{tabular}

* excluded from further analyses

questionnaire items and were instructed in interviewing techniques, including the verbal and non-verbal aspects of interviewing. All interviewers received an written interviewer guide, covering the following aspects:

-Preparing for the interview (knowledge of the questionnaire, paying attention to the environment, etc.); -Introducing and starting the interview (informing the respondent about the duration and the anonymity of their comments);

- The interview itself (how to ask questions, what to do when a respondent does not understand the question or becomes emotional);

-Finishing the interview (informing the respondent about what will be done with the answers).

To minimize interviewer variation, all new interviewers were supervised by experienced interviewers. Meetings were held regularly to allow discussion about the function of interviewing and the robustness of the data collected. At the end of the study, interviewers, Prismant, and institutions discussed about how the interviews had been conducted. In a health care institution 30 interviews were conducted. A resident was interviewed once by one interviewer. In a health care institution a pair of interviewers interviewed all 30 residents. Pairs of interviewers were randomly assigned to the healthcare institutions all over the country with every health care institution a different combination of interviewers. The interviewers who participated in this research have been conducted interviews in at least five health care institutions.

\section{Interviewer characteristics}

Since the research question was whether experienced interviewers influence the perceived quality of healthcare services reported by residents, only interviewers were included who conducted at least 70 interviews during this research. The interviewers were asked to complete a questionnaire about a number of characteristics suggested to play a role in interviewer bias [22,23], namely, age, sex, level of education, socioeconomic status, work and previous interviewing experience before this research, general knowledge of healthcare and specific knowledge of care for the elderly in particular (Table 2). Other factors that can possibly influence the outcome of the interview, as determined by an expert panel, were also added to the questionnaire. These were health status, work motivation (intrinsic or economic reasons; an interviewer received $€ 30$,- per completed interview), frequency of interviewing (number of days per month), and whether the interviewers felt uncomfortable with the content of CQ Index.

At the time of data analysis, 4 of the 18 interviewers were no longer traceable and one interviewer had died. The remaining 13 interviewers received the questionnaire, of which 10 were completed and returned. (76.9\%).

\section{Analysis}

Inter-interviewer differences in respondents' scores for the quality-of-care dimensions of the CQ Index were

\section{Table 2 Characteristics of the residents $(N=4345)$}

\begin{tabular}{ll}
\hline & $\%$ \\
\hline Length of stay in a nursing home or home for the elderly & \\
< 1/2 year & $9.5 \%$ \\
6 months - 1 year & $14.0 \%$ \\
$1-2$ years & $18.7 \%$ \\
$2-5$ year & $32.2 \%$ \\
> 5 year & $25.5 \%$ \\
Health status - good & $44.9 \%$ \\
- moderate & $45.5 \%$ \\
- poor & $9.6 \%$ \\
Type of care - homes for the elderly & $83,6 \%$ \\
- nursing homes & $16,4 \%$ \\
Age - < 65 years & $4.3 \%$ \\
- 65 -74 years & $7,5 \%$ \\
- 75 -84 years & $34,6 \%$ \\
- > 85 years & $53,6 \%$ \\
Sex Man & $25.3 \%$ \\
Woman & $74.7 \%$ \\
Level of education & \\
- no education & $3.0 \%$ \\
- lower education & $74.6 \%$ \\
- medium education & $16.2 \%$ \\
- higher education & $6.0 \%$ \\
\hline
\end{tabular}


assessed using variance analysis. The data we used was cross-classified. The cross-classification was at level 2 (interviewer) with level 1 (residents) and the level 1 units (residents) were also nested in health care institutions (level 2) because the interviewers worked in different health care institutions.

In a multilevel model we investigated the degree of correlation of observations made by interviewers within a health care institution. We also investigated whether the differences in the scores on the dimensions of the CQ Index could be explained by resident characteristics, interviewer characteristics, or by a resident $x$ interviewer interaction. We started with lower level characteristics (resident) before entering higher-level characteristics (interviewer) and the interviewer $\times$ resident interaction. Only characteristics that were significantly correlated with the quality dimensions $(\mathrm{p} \leq .05)$ were included in the model. We built a multilevel model in five steps.:

- Model 0: model with no random effects of health care institutions or interviewer

- Model 1: random intercept model (interviewer and institution).

- Model 2: random intercept model, adjusting for resident characteristics.

- Model 3: random intercept model, adjusting for interviewer characteristics.

- Model 4: random intercept model, adjusting for resident characteristics as well as interviewer characteristics.

- Model 5: random intercept model, adjusting for resident and interviewer characteristics and interactions between resident and interviewer.

In all models, all variables were entered as fixed effects.

In Model 5, no interaction effects were found that could be explained by the interaction. Therefore, the interaction effects were excluded from further analysis.

The intra class correlation (ICC) [12,31] was measured as a size of the correlation between observations (interviews with residents) made by interviewers within a institution. The analysis was carried out using SPSS, version 15. Residual analysis was performed and all independent variables were standardized, which enabled comparison of the effects. Deviance tests or likelihood ratio tests were used to compare the relative fit of the different models. The difference in deviance of two nested models has a $\chi^{2}$ distribution with degrees of freedom equal to the number of additional parameters in the larger model. Results were considered statistically significant at a two-sided $\mathrm{p} \leq .05$ level. The percentage of explained variance was computed.
We gave health care institutions a star on every quality dimension $(1=$ worst and $5=$ best $)$. To assign the stars, we calculated a predicted quality score for each dimension, adjusted for resident characteristics (age, duration of stay, level of education, and health status) [12]. In the next step of the analysis, we corrected the raw scores on all dimensions of the CQ Index for each institution, for the characteristics of the residents (age, duration of stay, educational level, health status) and interviewers (age, educational level, sex and previous interview experience [22]) that were found to be significant. Subsequently, using these scores, all individual institutions were labelled with stars, based on the relative score of an institution in relation to the mean score of all institutions using 95\% confidence intervals (CI).

For each institution the number of stars assigned before and after

adjusting for interviewer and resident characteristics were compared and calculated the percentage of institutions that was assigned a different number of stars.

\section{Results}

\section{Resident and interviewer characteristics}

Eighteen interviewers were included. Together they had performed 4345 interviews. On average, an interview lasted 43.2 minutes ( $\mathrm{sd} \pm 11.8$ ), and an interviewer carried out 127 interviews; the maximum number of interviews carried out by one person was 512 and the minimum was 70 interviews. The mean age was 83.1 years (sd 11.4), $74.7 \%$ was women and $96.4 \%$ of the residents was born in the Netherlands. Of the residents $44.9 \%$ considered their health to be good, $9.6 \%$ as poor, and $45.5 \%$ as good neither poor. Other characteristics of the residents are shown in Table 2.

Of the interviewers, two were men. Ninety percent of the interviewers were highly educated, and all were born in the Netherlands. All interviewers had more than 6 years of working experience; $80 \%$ more than 10 years. Of $70 \%$ of the interviewers, their previous jobs were not related to interviewing (teacher, researcher, engineer, healthcare worker, etc.) (Table 3). In the non-response analysis, there were more men and younger individuals among the non-responders. The mean interview duration was similar between responders and nonresponders.

\section{Differences in scores on quality dimensions caused by interviewer of resident characteristics}

Analysis showed that the scores on the various quality dimensions varied significantly between interviewers (all $\mathrm{p}<0.001$ ). All resident characteristics were significantly correlated to at least three dimensions of the CQ Index, whereas previous interviewer experience, sex, reason for 
Table 3 Characteristics of the experienced interviewers ( $\mathbf{N}=10)$

\begin{tabular}{ll}
\hline & $\%$ \\
\hline Sex Men & $20 \%$ \\
Women & $80 \%$ \\
Age 30-39 & $10 \%$ \\
$40-49$ & $30 \%$ \\
$50-59$ & $40 \%$ \\
$60-69$ & $20 \%$ \\
Reason for interviewing Nice work & $30 \%$ \\
Flexible work schedule & $20 \%$ \\
Earn money & $10 \%$ \\
$\quad$ Useful spending of time & $30 \%$ \\
How many days interviewing per month 2-4 days in a month & $40 \%$ \\
5-7 days in a month & $20 \%$ \\
8-10 days in a month & $20 \%$ \\
$\quad>10$ days in a month & $10 \%$ \\
How long interviewing with CQ Index Between 4 and 6 & $30 \%$ \\
months & \\
Between 7 and 9 months & $20 \%$ \\
More than 9 months & $50 \%$ \\
Previous interview experience Yes & $50 \%$ \\
No & $50 \%$ \\
Knowledge of healthcare Strongly agree & $10 \%$ \\
Agree & $60 \%$ \\
Disagree & $30 \%$ \\
Anowledge of elderly care Strongly agree & $10 \%$ \\
Disagree & $70 \%$ \\
\hline & $20 \%$ \\
\hline
\end{tabular}

interviewing and content of the questionnaire were correlated to two or more dimensions (Table 4).

In additional file 1 , Table S1, the $-2 \log$ likelihood and $\chi^{2}$ of every quality dimension are shown, and decreased from model 1 to model 4 . Only characteristics that were significantly correlated to the quality dimensions ( $\mathrm{p} \leq$ $.05)$ were included in the model. We determined the -2loglikelihood compared with the previous model.

Table S1, in additional file 1, shows the level of homogeneity between interviewer observations (measured in the same health care institution), explained by interviewer characteristics and resident characteristics on the dimensions. In multilevel analysis, resident characteristics, especially sex, health status and type of care significantly influenced the scores given to the dimensions. Women were more positive than men. Residents with a higher educational level were less positive about several dimensions, as were residents with a better health status. Residents of nursing homes were more negative about healthcare than residents of homes for the elderly. Residents with a higher length of stay were more positive about the information services and the living environment, but were more negative about meals, comfort, and the availability of personnel.

Of the interviewers characteristics, previous interviewing experience was found to significantly affect how residents scored the meals and availability of personnel. The more previous experience the interviewer had, the more negative residents were. On the quality dimension 'autonomy' two interviewer characteristics were found significantly. The more the interviewer did this job for other reasons than economical reasons, the more negative residents were. The more knowledge of health care the interviewers have, the more positive residents were.

Table 5 shows the ICC's of the models. We compared the raw ICC (model 1) with the ICC adjusted for resident and interviewer characteristics (models 2 and 3). The ICC's in model 2 (only resident characteristics) were lower than the raw ICC's for 10 of the twelve quality indicators. Adjustment for resident characteristics is relevant, but the effect on the ICC is minor for the most quality dimensions ( $\max 1.8 \%$ ). Only for 'Living environment/privacy', the effect is substantial (7.5\%).

The ICC's of model 3 (interviewer characteristics) were lower then the ICC's of model 1 for five of the ten quality dimensions. Adjusting for interviewer characteristics also shows limited decrease of the ICC's (with $\max 4.7 \%$ ). On five of the ten quality dimensions the ICC's were increasing, but not substantial ( $\max 1.3 \%)$.

The ICC's of model 4 were lower than the raw ICC's in model 1 in five of the ten quality dimensions ( $\max$ 4.9).

\section{Differences in star assignment to institutions}

We calculated to what extent interviewer characteristics (as part of the interviewer effect) affected the overall star assignment to the healthcare institutions (table 6). Interviewer and resident characteristics did not affect the star assignment for any institutions for seven of the CQ Index dimensions, changed the star assignment to 1 of the 133 institutions (0.8\%) of the three CQ Index dimensions "Meals", "Autonomy", and "Availability personnel" and altered the star assignment to 3 of the 133 institutions (2.3\%) of the CQ Index dimension "Shared decision-making", and altered the star assignment to $13,5 \%$ of the institutions of the CQ Index dimension "Professional competency".

\section{Discussion}

We investigated whether characteristics of interviewers who conducted a major number of interviews influenced the way the residents of nursing homes and homes for the elderly scored the dimensions of the CQ Index, which measures residents' experience of the healthcare services provided. Despite their experience, the use of a 


\begin{tabular}{|c|c|c|c|c|c|c|c|c|c|c|c|c|c|c|c|c|c|c|c|c|}
\hline Dimensions & $\begin{array}{l}\text { Length } \\
\text { of } \\
\text { stay }\end{array}$ & Sex & Age & Education & $\begin{array}{l}\text { Health } \\
\text { status }\end{array}$ & $\begin{array}{l}\text { Type } \\
\text { of } \\
\text { care }\end{array}$ & Sex & Age & Education & Reason & SES & $\begin{array}{c}\text { Work } \\
\text { experience }\end{array}$ & $\begin{array}{l}\text { Previous } \\
\text { Interview } \\
\text { experience }\end{array}$ & $\begin{array}{c}\text { How } \\
\text { long } \\
\text { interviewing }\end{array}$ & $\begin{array}{l}\text { Frequency } \\
\text { interviewing }\end{array}$ & $\begin{array}{l}\text { Other } \\
\text { jobs }\end{array}$ & $\begin{array}{c}\text { Content } \\
\text { questionnaire }\end{array}$ & $\begin{array}{l}\text { Knowledge } \\
\text { healthcare }\end{array}$ & $\begin{array}{l}\text { Knowledge } \\
\text { elderly care }\end{array}$ & $\begin{array}{l}\text { Health } \\
\text { status }\end{array}$ \\
\hline 1 & .01 & $-.06^{*}$ & .02 & -.05 & $-.08^{*}$ & $.07^{*}$ & -.33 & .15 & -.41 & -.20 & -.09 & .14 & .08 & .14 & $.68^{*}$ & -.23 & $-.66^{*}$ & -.06 & -.30 & -.40 \\
\hline 2 & -.01 & .01 & -.01 & .03 & $.11^{*}$ & .04 & -.50 & .16 & .30 & $.59^{*}$ & -.10 & -.29 & -.18 & .21 & -.14 & .11 & .14 & .33 & .03 & -.06 \\
\hline 3 & $.05^{*}$ & -.02 & .02 & .04 & $.15^{*}$ & $.09^{*}$ & -.06 & -.14 & .51 & .55 & .20 & -.27 & $-.61^{*}$ & .06 & -.37 & .26 & $.58^{*}$ & .14 & .07 & .23 \\
\hline 4 & $-.14^{*}$ & -.04 & .03 & -.03 & .01 & $.10^{*}$ & -.29 & -.39 & $.64^{*}$ & -.05 & .10 & .01 & -.53 & .24 & -.36 & .13 & .04 & .26 & .16 & .42 \\
\hline 6 & $.06^{*}$ & $-.09^{*}$ & .03 & $.05^{*}$ & $.13^{*}$ & $.08^{*}$ & $.61^{*}$ & -.29 & .40 & .10 & .52 & -.13 & $-85^{*}$ & .016 & -.17 & -.17 & .51 & -.40 & -.28 & $.62^{*}$ \\
\hline 7 & .05 & .01 & -.00 & $.06^{*}$ & $.18^{*}$ & .04 & -.08 & -.24 & .29 & -.26 & -.01 & -.37 & -.54 & -.10 & -.08 & .13 & .10 & .10 & -.03 & .10 \\
\hline 8 & $.11^{*}$ & $-.13^{*}$ & .01 & .04 & $.15^{*}$ & -.03 & .52 & -.53 & .19 & -.19 & .03 & -.36 & $-.65^{*}$ & -.45 & -.08 & -.01 & .07 & -.16 & .05 & .38 \\
\hline 9 & .00 & -.03 & $-.05^{*}$ & $.07^{*}$ & $.14^{*}$ & $.18^{*}$ & .33 & -.18 & .36 & .27 & .05 & -.35 & $-.68^{*}$ & -.08 & -.31 & -.09 & .47 & .04 & .05 & .43 \\
\hline 10 & $-.14^{*}$ & .01 & $-.05^{*}$ & $.05^{*}$ & $.08^{*}$ & $.33^{*}$ & -.03 & .09 & .06 & .20 & -.22 & -.52 & .04 & -.29 & -.20 & -.36 & -.14 & .21 & .25 & -.18 \\
\hline 12 & -.03 & $-.06^{*}$ & $-.06^{*}$ & .02 & $.18^{*}$ & $.37^{*}$ & $.56^{*}$ & .02 & .07 & $.39^{*}$ & .48 & -.39 & $-.65^{*}$ & .20 & .07 & -.12 & .35 & $-.76^{*}$ & $-.62^{*}$ & .18 \\
\hline 14 & -.01 & $-.07^{*}$ & -.02 & $-.06^{*}$ & $.10^{*}$ & $.07^{*}$ & .12 & $-.81^{*}$ & .17 & $-.59^{*}$ & .12 & -.04 & -.49 & $-.57^{*}$ & -.00 & .50 & -.22 & -.03 & .13 & -.01 \\
\hline 15 & $.07^{*}$ & -.04 & -.07 & $.09^{*}$ & $.21^{*}$ & $.11^{*}$ & .17 & -.29 & .22 & .23 & -.03 & -.52 & $-.58^{*}$ & -.23 & -.11 & .07 & .08 & -.09 & -.08 & .10 \\
\hline
\end{tabular}

$1=$ Care plan and evaluation $2=$ Shared decision-making $3=$ Treatment. $4=$ Information $6=$ Meals $7=$ Professional competency $8=$ Living comfort $9=$ Atmosphere $10=$ Living environment and privacy $12=$ Autonomy $14=$ Security $15=$ Availability personnel

Note: Reference category for type of care is homes for the elderly (1).

* is significant at the $p \leq .05$ level.

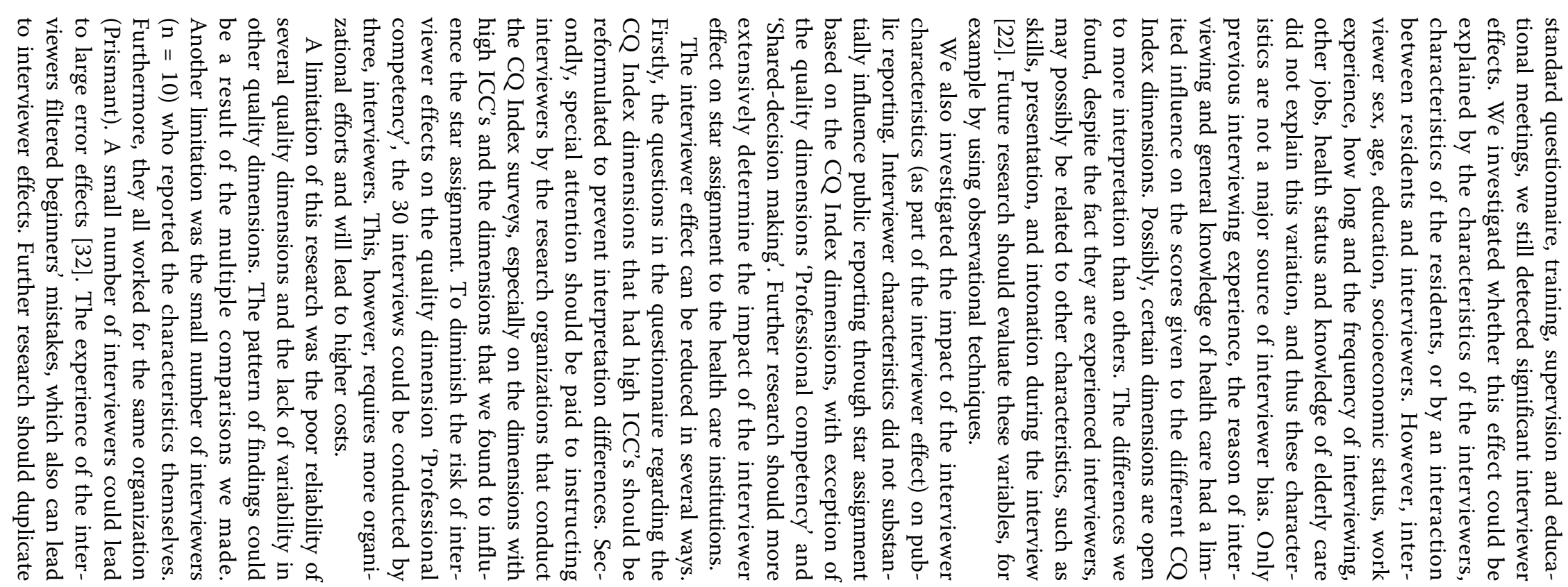


Table 5 ICC on the dimensions of the CQ Index, per model

\begin{tabular}{|c|c|c|c|c|c|c|c|c|c|c|}
\hline \multirow[t]{2}{*}{ Dimensions } & \multirow[t]{2}{*}{$\begin{array}{l}\text { Model } 0 \text { no random } \\
\text { intercept }\end{array}$} & \multirow[t]{2}{*}{2 Levels } & \multicolumn{2}{|c|}{$\begin{array}{l}\text { Model } 1 \text { random } \\
\text { intercept }\end{array}$} & \multicolumn{2}{|c|}{$\begin{array}{c}\text { Model } 2 \text { random } \\
\text { intercept and level } 1 \\
\text { independent } \\
\text { variables }\end{array}$} & \multicolumn{2}{|c|}{$\begin{array}{c}\text { Model } 3 \text { random } \\
\text { intercept and } \\
\text { level } 2 \\
\text { explanatory } \\
\text { variables }\end{array}$} & \multicolumn{2}{|c|}{$\begin{array}{c}\text { Model } 4 \text { random } \\
\text { intercept with } \\
\text { level } 1 \text { and } 2 \\
\text { variables }\end{array}$} \\
\hline & & & ICC & $\begin{array}{l}\text { Explained } \\
\text { variance }\end{array}$ & ICC & $\begin{array}{l}\text { Explained } \\
\text { variance }\end{array}$ & ICC & $\begin{array}{l}\text { Explained } \\
\text { variance }\end{array}$ & ICC & $\begin{array}{l}\text { Explained } \\
\text { variance }\end{array}$ \\
\hline \multirow[t]{2}{*}{$\begin{array}{l}\text { 1. Care plan and } \\
\text { evaluation }\end{array}$} & 0.881 & $\begin{array}{l}\text { Interv } \\
\text { level }\end{array}$ & 0.064 & $7.39 \%$ & 0.063 & $7.30 \%$ & 0.017 & $1.97 \%$ & 0.019 & $2.18 \%$ \\
\hline & & $\begin{array}{l}\text { Facility } \\
\text { level }\end{array}$ & 0.083 & $9.54 \%$ & 0.082 & $9.48 \%$ & 0.078 & $8.94 \%$ & 0.073 & $8.42 \%$ \\
\hline \multirow[t]{2}{*}{$\begin{array}{l}\text { 2. Shared decision- } \\
\text { making }\end{array}$} & 0.671 & $\begin{array}{l}\text { Interv } \\
\text { level }\end{array}$ & 0.119 & $15.87 \%$ & 0.113 & $15.48 \%$ & 0.120 & $16.59 \%$ & 0.120 & $16.64 \%$ \\
\hline & & $\begin{array}{l}\text { Facility } \\
\text { level }\end{array}$ & 0.060 & $8.04 \%$ & 0.060 & $8.17 \%$ & 0.036 & $4.95 \%$ & 0.036 & $4.95 \%$ \\
\hline \multirow[t]{2}{*}{ 3. Treatment } & 0.439 & $\begin{array}{l}\text { Interv } \\
\text { level }\end{array}$ & 0.029 & $8.98 \%$ & 0.029 & $8.40 \%$ & 0.033 & $10.00 \%$ & 0.034 & $10.60 \%$ \\
\hline & & $\begin{array}{l}\text { Facility } \\
\text { level }\end{array}$ & 0.018 & $5.00 \%$ & 0.013 & $3.84 \%$ & 0.016 & $4.73 \%$ & 0.013 & $3.92 \%$ \\
\hline \multirow[t]{2}{*}{ 4. Information } & 0.61 & $\begin{array}{l}\text { Interv } \\
\text { level }\end{array}$ & 0.073 & $9.08 \%$ & 0.072 & $9.31 \%$ & 0.027 & $3.73 \%$ & 0.029 & $4.11 \%$ \\
\hline & & $\begin{array}{l}\text { Facility } \\
\text { level }\end{array}$ & 0.059 & $7.35 \%$ & 0.052 & $6.67 \%$ & 0.095 & $13.11 \%$ & 0.089 & $12.72 \%$ \\
\hline \multirow[t]{2}{*}{ 6. Meals } & 0.74 & $\begin{array}{l}\text { Interv } \\
\text { level }\end{array}$ & 0.026 & $3.81 \%$ & 0.026 & $3.95 \%$ & 0.006 & $0.92 \%$ & 0.004 & $0.74 \%$ \\
\hline & & $\begin{array}{l}\text { Facility } \\
\text { level }\end{array}$ & 0.055 & $7.99 \%$ & 0.054 & $8.23 \%$ & 0.055 & $9.05 \%$ & 0.059 & $10.06 \%$ \\
\hline \multirow[t]{2}{*}{$\begin{array}{l}\text { 7. Professional } \\
\text { competency }\end{array}$} & 0.22 & $\begin{array}{l}\text { Interv } \\
\text { level }\end{array}$ & 0.022 & $9.09 \%$ & 0.020 & $8.62 \%$ & & & & \\
\hline & & $\begin{array}{l}\text { Facility } \\
\text { level }\end{array}$ & 0.015 & $6.29 \%$ & 0.014 & $6.18 \%$ & & & & \\
\hline \multirow[t]{2}{*}{ 8. Living comfort } & 0.677 & $\begin{array}{c}\text { Interv } \\
\text { level }\end{array}$ & 0.028 & $4.12 \%$ & 0.024 & $3.68 \%$ & 0.023 & $3.69 \%$ & 0.019 & $3.19 \%$ \\
\hline & & $\begin{array}{l}\text { Facility } \\
\text { level }\end{array}$ & 0.068 & $9.96 \%$ & 0.066 & $10.07 \%$ & 0.073 & $11.92 \%$ & 0.073 & $12.42 \%$ \\
\hline \multirow[t]{2}{*}{ 9. Atmosphere } & 0.234 & $\begin{array}{l}\text { Interv } \\
\text { level }\end{array}$ & 0.024 & $9.62 \%$ & 0.023 & $9.85 \%$ & 0.024 & $10.66 \%$ & 0.022 & $10.42 \%$ \\
\hline & & $\begin{array}{l}\text { Facility } \\
\text { level }\end{array}$ & 0.025 & $10.24 \%$ & 0.018 & $7.57 \%$ & 0.024 & $10.99 \%$ & 0.020 & $9.23 \%$ \\
\hline \multirow[t]{2}{*}{$\begin{array}{l}\text { 10. Living } \\
\text { environment/privacy }\end{array}$} & 0.125 & $\begin{array}{l}\text { Interv } \\
\text { level }\end{array}$ & 0.002 & $19.51 \%$ & 0.002 & $23.61 \%$ & & & & \\
\hline & & $\begin{array}{l}\text { Facility } \\
\text { level }\end{array}$ & 0.028 & $32.24 \%$ & 0.014 & $19.51 \%$ & & & & \\
\hline \multirow[t]{2}{*}{ 12. Autonomy } & 0.418 & $\begin{array}{l}\text { Interv } \\
\text { level }\end{array}$ & 0.036 & $8.12 \%$ & 0.034 & $9.64 \%$ & 0.000 & $0.00 \%$ & 0.002 & $0.54 \%$ \\
\hline & & $\begin{array}{l}\text { Facility } \\
\text { level }\end{array}$ & 0.116 & $26.39 \%$ & 0.049 & $13.82 \%$ & 0.092 & $23.52 \%$ & 0.051 & $15.32 \%$ \\
\hline \multirow[t]{2}{*}{ 14. Security } & 0.294 & $\begin{array}{l}\text { Interv } \\
\text { level }\end{array}$ & 0.008 & $26.23 \%$ & 0.009 & $3.20 \%$ & 0.000 & $0.07 \%$ & 0.001 & $0.49 \%$ \\
\hline & & $\begin{array}{l}\text { Facility } \\
\text { level }\end{array}$ & 0.004 & $14.50 \%$ & 0.002 & $5.89 \%$ & 0.001 & $0.40 \%$ & 0.000 & $0.10 \%$ \\
\hline \multirow[t]{2}{*}{$\begin{array}{l}\text { 15. Availability } \\
\text { personnel }\end{array}$} & 0.338 & $\begin{array}{l}\text { Interv } \\
\text { level }\end{array}$ & 0.028 & $6.58 \%$ & 0.029 & $7.29 \%$ & 0.020 & $5.41 \%$ & 0.025 & $6.73 \%$ \\
\hline & & $\begin{array}{l}\text { Facility } \\
\text { level }\end{array}$ & 0.046 & $10.98 \%$ & 0.035413 & $8.89 \%$ & 0.018 & $11.70 \%$ & 0.038 & $10.45 \%$ \\
\hline
\end{tabular}

ICC = Intra Class Correlation, recorded as $\%$ of explained variance by variables included in the model 
Table 6 Changes in star assignments to institutions for the care of the elderly

\begin{tabular}{|c|c|c|c|c|}
\hline Dimensions & $\begin{array}{l}\text { Changes in } \\
\text { scores }\end{array}$ & $\begin{array}{l}\text { Total percentage } \\
\text { of discrepancy }\end{array}$ & $\begin{array}{l}\text { Total nursing } \\
\text { homes }\end{array}$ & $\begin{array}{l}\text { Total homes } \\
\text { for the elderly }\end{array}$ \\
\hline Care plan and evaluation & 0 & $0.00 \%$ & 0 & 0 \\
\hline Shared decision-making & 3 of 133 institutes & $2.26 \%$ & 0 & 3 \\
\hline Treatment & 0 & $0.00 \%$ & 0 & 0 \\
\hline Information & 0 & $0.00 \%$ & 0 & 0 \\
\hline Meals & 1 of 133 institutes & $0.75 \%$ & 1 & 0 \\
\hline Professional competency & 10 of 74 institutes & $13.51 \%$ & 0 & 10 \\
\hline Living comfort & 0 & $0.00 \%$ & 0 & 0 \\
\hline Atmosphere & 0 & $0.00 \%$ & 0 & 0 \\
\hline Living environment/privacy & 0 & $0.00 \%$ & 0 & 0 \\
\hline Autonomy & 1 of 133 institutes & $0.75 \%$ & 0 & 1 \\
\hline Security & 0 & $0.00 \%$ & 0 & 0 \\
\hline Availability personnel & 1 of 133 institutes & $0.75 \%$ & 0 & 1 \\
\hline
\end{tabular}

our study including more interviewers and more residents, including interviewers from different research organizations (introducing another level of possible interviewer effects) and interviewers with less experience. Ranking institutions with a multilevel approach with several levels: resident, interviewer, research organization and health care institution (cross level classified design) can determine the impact of the interviewer effects on the CQ Index dimensions for public reporting and can give suggestions for a minimum of conducted interviews.

\section{Conclusions}

We have shown that training, the use of experienced interviewers, interview guides, supervision and educational meetings do not automatically prevent interviewer effects. Data control during and after the investigation is still necessary. Our findings suggest that the results for some CQ Index dimensions ("Professional competency" and "Shared-decision making") published on a public website should be interpreted with caution, especially when used for accountability and transparency. This can be done by combining the CQ Index results with additional information from other sources (for example healthcare indicators) to provide a more complete and balanced view of the quality of healthcare organizations. Other quality dimensions are reliable enough for accountability and transparency despite the influence of the interviewer.

\section{Additional material}

Additional file 1: Table S1 Study results of the interviewer effect on the dimensions of the CQ Index, per model.

\section{Author details}

${ }^{1}$ Kiwa Prismant, P.O. Box 85200, 3508 AE Utrecht, the Netherlands. ${ }^{2}$ Erasmus University Rotterdam, institute of Health Policy and Management, Rotterdam, the Netherlands. ${ }^{3}$ Department of Social Medicine, Academic Medical Centre, University of Amsterdam, Amsterdam, the Netherlands.

\section{Authors' contributions}

SW performed the design of the research, collected data and performed the multilevel analysis. MS contributed in the analysis and the interpretation of data. TK, NK and $\mathrm{RH}$ have been involved in writing, reading and commenting on the manuscript and assisted in the design of the study. All authors read and approved the final manuscript.

\section{Competing interests}

The authors declar that they have no competing interests.

Received: 12 July 2009 Accepted: 19 August 2010

Published: 19 August 2010

\section{References}

1. Aharony L, Strasser S: Patient satisfaction: what we know about and what we still need to explore. Med Care Rev 1993, 50:49-79.

2. Barr DA, Vergun P: Using a new method of gathering patient satisfaction data to assess the effects of organizational factors on primary care quality. Jt Comm J Qual Improv 2000, 26:713-723.

3. Boyer L, Francois P, Doutre E, Weil G, Labarere J: Perception and use of the results of patient satisfaction surveys by care providers in a French teaching hospital. Int J Qual Health Care 2006, 18:359-64.

4. Bradley EH, Holmboe ES, Mattera JA, Roumanis SA, Radford MJ, Krumholz HM: Data feedback efforts in quality improvement: lessons learned from US hospitals. Qual Saf Health Care 2004, 13:26-31.

5. Carey $\mathrm{RG}$, Seibert $\mathrm{JH}:$ A patient survey system to measure quality improvement: questionnaire reliability and validity. Med Care 1993, 31:834-845.

6. Castle NG, Brown J, Hepner KA, Hays RD: Review of the literature on survey instruments used to collect data on hospital patients' perceptions of care. Health Serv Res 2005, 40:1996-2017.

7. Davies E, Cleary PD: Hearing the patient's voice? Factors affecting the use of patient survey data in quality improvement. Qual Saf Health Care 2005, 14:428-432.

8. Harris LE, Swindle RW, Mungai SM, Weinberger M, Tierney WM: Measuring patient satisfaction for quality improvement. Med Care 1999, 37:1207-1213.

9. Sitzia J, Wood N: Patient satisfaction: a review of issues and concepts. Soc Sci Med 1997, 45:1829-1843. 
10. Solberg $L I$, Mosser G, McDonald S: The three faces of performance measurement: improvement, accountability, and research. Jt Comm J Qual Improv 1997, 23:135-147.

11. Strasser S, Aharony L, Greenberger D: The patient satisfaction process: moving toward a comprehensive model. Med Care Rev 1993, 50:219-248.

12. Triemstra M, Winters $S$, Kool RB, Wiegers TA: Measuring client experiences in long-term care in the Netherlands: a pilot study with the Consumer Quality Index Long-term Care. BMC Health Services Research 2010, 10:95.

13. Wensing $M$, Vingerhoets $E$, Grol R: Feedback based on patient evaluations: a tool for quality improvement? Patient Educ Couns 2003, 51:149-153.

14. Williams B: Patient satisfaction: a valid concept? Soc Sci Med 1994, 38:509-516

15. Brouwer W, Gelsema T, Delnoij DMJ: The role of CAHPS/patient experiences in the Dutch health care system: developing a questionnaire for patients who underwent cataract surgery or total hip or knee arthroplasty. European Journal of Public Health 2005, 15:17-18.

16. Delnoij DMJ, Arah OA, de Koning JS, Stam S, Poll A, Vriens B, Schmidt P, Klazinga NS: Made in the USA: the import of American Consumer Assessment of Health Plan Surveys (CAHPS) into the Dutch social insurance system. European Journal of Public Health 2004, 14(4):43.

17. Rupp I, Arah OA, Poll A, Stam S, Schmidt P, Vriens B, de Koning JS: The role of patients' experiences in the Dutch Health Care System: validation and discriminative ability of the Dutch version of the Hospital CAHPS ${ }^{\circ}$ Instrument. European Journal of Public Health 2005, 15(Supplement 1):18-19(3).

18. Stubbe JJ, BW\&DDMJ: Patients' experiences with quality of hospital care: the Consumer Quality Index Cataract Questionnaire. BMC Ophthalmology 2007, 7:14.

19. Marcus A, Crane L: Telephone Surveys in Public Health Research. Medical Care 1986, 24(2):97-112.

20. Worth A, Tierney AJ: Conducting research interviews with elderly people by telephone. Journal of Advanced Nursing 1993, 18:1077-1084.

21. Herzog AR, Rodgers WL, Kulka RA: Interviewing older adults: A Comparison of Telephone and Face-to-Face Modalities. Public Opinion Quarterly 1983, 47:405-418.

22. Hox JJ, Leeuw dE, Kreft IGG, In Biemer GLMSe: The effect of interviewer and respondent characteristics on quality of survey data: a mulitlevel model. Measurement Errors in Surveys 1991, 439-461.

23. Johannes CB, Crawfort SL, McKinlay JB: Interviewer effects in a cohort study, results from the Massachusetts women health study. Am $J$ Epidemiol 1997, 146(5):429-438.

24. Lyberg L, Kasprzyk D, In Biemer GLMSe: Data collection methods and measurement error: an overview. Measurement Errors in Surveys 1991, 237-257.

25. Clarcke P, Spronston K, Thomas R: An investigation into expectation-led interviewer effects in health surveys. Social Science \& Medicine 2003, 56.

26. Fowler JF Jr: Reducing interviewer-Related Error Through Interviewer training, Supervision, and Other means. Measurement Errors in Surveys 1991, 259-278.

27. Schaeffer NC: Conversation with a purpose - or conversation? interaction in the standardized interview. Measurement Errors in Surveys 1994, 237-257.

28. Russel C: Interviewing vulnerable old people: Ethical and methodological implications of imagining our subjects. Journal of aging studies 1999, 13(4):403-417.

29. Berkman CS, Leipzig M, Greenberg SA, Inouye SK: Methodologic Issues in Conducting Research on Hospitalized Older People. J Am Geriatr Soc 2001, 49:172-178.

30. Wilson $\mathrm{K}$, Roe B: Interviewing older people by telephone following initial contact by postal survey. Journal of Advanced Nursing 1998, 27:575-581.

31. Snijders $T A B$, Bosker RJ: Multilevel analysis: An introduction to basic and advanced multilevel modeling. London: SAGE Publications Ltd 2004.

32. Davis $P$, Scott A: The effect of interviewer variance on domain comparisons. Survey Methodology 1995, 21:99-106.

\section{Pre-publication history}

The pre-publication history for this paper can be accessed here: http://www.biomedcentral.com/1471-2288/10/75/prepub

doi:10.1186/1471-2288-10-75

Cite this article as: Winters et al:: Determining the interviewer effect on CQ Index outcomes: a multilevel approach. BMC Medical Research Methodology 2010 10:75.

\section{Submit your next manuscript to BioMed Central and take full advantage of:}

- Convenient online submission

- Thorough peer review

- No space constraints or color figure charges

- Immediate publication on acceptance

- Inclusion in PubMed, CAS, Scopus and Google Scholar

- Research which is freely available for redistribution

Submit your manuscript at www.biomedcentral.com/submit
Biomed Central 